\title{
Social Responsibility and Corporate Sustainability Factors in Mexico*
}

Factores de responsabilidad social y sustentabilidad empresarial en México Fatores de responsabilidade social e
sustentabilidade empresarial no México

\section{Fernando Lámbarry Vilchis ${ }^{* *}$}

Fecha de recibido: 30 de septiembre de 2015

Fecha de aprobado: 19 de enero de 2016

Doi: http://dx.doi.org/10.12804/rev.univ.empresa.31.2016.05

Para citar: Lámbarry Vilchis, F. (2016). Social Responsibility and Corporate Sustainability Factors in Mexico. Universidad \& Empresa 18/31). 103-1 19. Doi: hitp://dx.doi.org/10.12804/rev.univ.empresa.31.2016.05

\section{ABSTRACT}

Corporate responsibility is still a secondary issue in most companies anywhere in the world. However, corporate responsibility and sustainability are increasingly common among businessmen, so that literature has emerged on various approaches to this type of case identifying the factors that compose them, which is the objective of this study, to the Mexican context. The research method is based on the documentary analysis of the main models of social responsibility and sustainability, and a hierarchical decision making analysis. The results provide a first theoretical approach to the management of companies in Mexico, allowing them to guide their operational strategies, and similarly for public

Este artículo es resultado del proyecto 20140682: Identificación de Factores de Responsabilidad Social y Sostenibilidad empresarial en México. Financiado por el Instituto Politécnico Nacional, México. Con el objetivo de identificar los factores de responsabilidad social y sustentabilidad empresarial a ser considerados por el sector empresarial mexicano.

** Doctor en Ciencias Administrativas del Instituto Politécnico Nacional. Es catedrático e investigador de la ESCA Santo Tomás del Instituto Politécnico Nacional. Es investigador candidato del Sistema Nacional de Investigadores del Consejo Nacional de Ciencia y Tecnología. Su línea de investigación gira en torno a la responsabilidad social empresarial, y complejidad de la gestión ambiental. Correo electrónico: flambarry@ipn.mx 
administrators, the development of public policies of responsibility and sustainability.

Keywords: Models of social corporate responsibility, models of corporate sustainability, social and sustainability corporate in Mexico.

\section{RESUMEN}

La responsabilidad corporativa es todavía un asunto secundario en la mayoría de las empresas de cualquier parte del mundo. Sin embargo, la responsabilidad y sostenibilidad corporativa son cada vez más comunes entre los empresarios con lo que ha surgido una naciente literatura bajo diversos enfoques para el caso de identificar los factores que los componen, lo cual es el objetivo de este estudio para el contexto mexicano. El método de investigación se fundamenta en el análisis documental de los principales modelos de responsabilidad social y sustentabilidad y un análisis jerárquico de toma de decisiones. Los resultados proporcionan un primer acercamiento teórico para que los directivos de las empresas en México orienten sus estrategias de operación y de igual forma, para los administradores públicos el desarrollo de políticas públicas de responsabilidad y sostenibilidad. Palabras clave: modelos de responsabilidad social empresarial, modelos de sustentabilidad empresarial, responsabilidad social y sustentabilidad empresarial en México.

\section{RESUMO}

A responsabilidade corporativa é ainda um assunto secundário na maioria das empresas de qualquer parte do mundo. No entanto, a responsabilidade e a sustentabilidade corporativa são cada vez mais comuns entre os empresários com o que tem surgido uma nascente literatura sob diversos enfoques para o caso de identificar os fatores que os compõem, o qual é o objetivo deste estudo para o contexto mexicano. O método de pesquisa se fundamenta na análise documental dos principais modelos de responsabilidade social e sustentabilidade e uma análise hierárquica de tomada de decisões. Os resultados proporcionam uma primeira aproximação teórica para que os diretivos das empresas no México orientem as suas estratégias de operação e, de igual maneira, para os administradores públicos o desenvolvimento de políticas públicas de responsabilidade e sustentabilidade.

Palavras-chave: modelos de responsabilidade social empresarial, modelos de sustentabilidade empresarial, responsabilidade social e sustentabilidade empresarial no México. 


\section{INTRODUCTION}

In the new stage of world economy where corporations rule the world, serious social problems prevail, and the operation of unhelpful economic models to solve them. There are plenty of activities that organizations perform, having repercussions on the deterioration of the environment and the planet. It is known that economic growth leads to counterpoised effects on the environment. An example of this, is the increase in income per capita which takes place from increased consumption of raw materials, and energy, generating more waste, and intensifying environmental problems (Labandeira, León, \& Vázquez, 2007).

It is for this reason that in the last decade, the business sector, besides generating returns for their shareholders, has also begun to contribute to some extent with the communities they are part of (Correa, Flynn \& Amit, 2004; World Business Council for Sustainable Development, 1998). They have become responsible for its operations, seeking sustainable development. However, beyond this voluntary commitment and compliance with regulatory and conventional obligations, companies do it in response to various social, environmental, and economic pressures (International Organization for Stan- dardization, 2010; Commission of the European Communities, 2001), rather than their own initiative to contribute to a better society.

Under this trend, there are various models and guidelines generated by international organizations that envision the importance of promoting these practices in the world, among the most cited are: that of the United Nations-GlobalCompact(1999), European Nations Commission (1999), Mexican Center for Philanthropy (2010), ISO 26000:2010 (2010), Global Report Initiative (2011), and Ethos(2011).Although aware of this, there are few studies on the factors of social responsibility and sustainability that should be considered by companies in their strategies, especially in the Mexican context characterized by conditions of increasing poverty, and a weak and dispersed public participation, in which corporate social responsibility is in a nascent stage of development (Lámbarry, Rivas \& Trujillo, 2015), result more from the market crisis, than by philanthropic convictions.

This study showed from a documentary analysis, and from the process of analysis of hierarchies (PAH), that the factors mentioned in the Ethos models, and ISO 26000, must complement the one of the Mexican Center for Philanthropy. 
These results provide a first theoretical approach for entrepreneurs in Mexico to re-orient the practices and strategies of social responsibility for sustainable development.

\section{CONTEXTUAL FRAMEWORK: THE MEXICAN CORPORATE SECTOR}

Micro, Small and Medium Enterprises (MSMEs), worldwide represent the segment of the economy that provides the largest number of economic units, and employed staff. They make up for more than $90 \%$ of all companies in most countries of the world (National Development Plan 2013-2018, 2013). In the European Union, and the United States, they account for $95 \%$ of the economic units, and provide over $75 \%$ of jobs (National Development Plan 2013-2018, 2013). Whereas in Mexico, MSMEs are four million fifteen thousand business units, that generate about $52 \%$ of Gross Domestic Product, they contribute about $34.7 \%$ of Gross Output Total, and generate $73 \%$ of jobs representing over 19.6 million of them (National Development Plan 2013-2018, 2013; National Institute of Statistics and Geography, 2009).

On the issue of social responsibility, in 2013, there were a total of 758 companies in Mexico with the insignia of socially responsible company, awarded by the Mexican Center for Philanthropy, of which, $50 \%$ were located in Mexico City, so it is in this entity that a growing trend is evident, with over 55 responsible companies by 2014 (Cemefi, 2014). Of these, in consideration to the size and sector, 16 are micro, 56 small, 53 are corporate, 56 medium, and 194 big. By sector, agriculture has 12 , commerce 32 , construction 25 , manufacturing 61, mining and oil extraction 8 , services 216 , and transport and communications 21 (Cemefi, 2014).

\section{THEORETICAL FRAMEWORK. COMPANIES: THEIR SOCIAL RESPONSIBILITY AND SUSTAINABILITY}

In specialized literature, it is repeatedly warned that organizations that incorporate social responsibility into their strategies, will be those that survive and develop in sustainable terms. Companies have realized that implementing policies, and corporate social responsibility actions, have benefited their reputation, value, and image, reducing the risk of public opposition to their operations (Correa, Flynn \& Amit, 2004). However, many companies that have published reports on sustainability or corporate social responsibility, seem to do so, only as a showcase, and not acting on their own recommendations (Strandberg, 2010). Nonetheless, 
more and more stakeholders, like the investors, are inclined to request or require information to the companies about the exercise of their social responsibility, largely by national and international regulations, and agreements requiring more responsible behavior from the private sector, which has led to a growing trend of publishing non-financial reports, in which social and environmental aspects are included. That is why, parallel to this, recommendations, standards and international initiatives have been developed for the preparation of these reports, which include, the Global Compact, the Global Reporting Initiative, SA 8000, AA 1000 , and most recently ISO 26000.

Attention is drawn to the fact that a measuring system of corporate social responsibility is not based in a legislative authority, it is the result of commitment and discretion of the company executives. Although there are different rules for it, most of them are compatible with each other, and complement different stages of the process for the organization to be more responsible and sustainable (Strandberg, 2010).

\subsection{Sizing social responsibility and corporate sustainability}

There are seven models of international organizations most cited in literature that guide an organization to be sustainable through its social responsibility: that of the United Nations (1999), of the Commission of European Nations (2001), the Mexican Center for Philanthropy (2010), the standard ISO 26000: 2010 (2010), the Global Report Initiative (2011), and Ethos (2011).

In the so-called Global Compact, in 1999, the United Nations link four fundamental rights in order to achieve the voluntary commitment of organizations on social responsibility, these are: human rights, labor standards, environment, and anti-corruption, derived from three declarations: the Universal Declaration of Human Rights, Principles of the International Labour Organization, and the one of Rio, on Environment and Development (United Nations, no year). The Global Compact is not an auditing standard, but encourages companies to use the Global Reporting Initiative guidelines as a means of communicating their progress (Strandberg, 2010).

The Committee of European Nations $(2001,2011)$ in the so-called Green Paper, proposes two dimensions for a company to be socially responsible: one internal, oriented towards employees, and another external, to local communities and various stakeholders as shareholders, business partners, and suppliers, consumers, public authorities, and environmental 
NGOs. From these two dimensions, the Commission promotes seven principles related to human resources management, which are: health and safety in the workplace; adaptation to change; environmental impact and natural resources management; local communities; business partners, suppliers and consumers, and; human rights.

For Latin America, through Ethos (2011) dialogue and commitment practices of the company with stakeholders are recognized and encouraged from an ethical and transparent relationship of social responsibility. All this with a focus on sustainable development. Ethos structures social responsibility in seven topics: values, transparency and corporate government, internal public, environment, suppliers, consumers and customers, community, government and society. Its model has a version for micro and small businesses to be incorporated into the actions of social responsibility. It even proposes specific indicators for each business sector that has correlated, with relevant international initiatives like the Global Compact, the Millennium Development Goals, SA8000, and the Guide for the Preparation of Sustainability Reports of the GRI (Global Reporting Initiative).

More recently, but participating since 2000, the Global Reporting Initia- tive (2011) has proposed guidelines under the Guide for the Preparation of Sustainability Reports of Organizations, through four principles regarding its content: materiality, stakeholder's participation, sustainability context and completeness. It dimensions the organization's social responsibility and sustainability from its economic, environmental, and social performance. In the social category it includes indicators to labor issues, human rights, society, and product responsibility. In the economic dimension in relation to economic and financial performance, market presence, and indirect economic impacts (investments in infrastructure, and services provided), and on environmental issues considers indicators on: materials, energy, water, biodiversity, emissions, discharges and waste, products and services, compliance, transport and general aspects.

Notwithstanding, beyond these models and guidelines, international efforts have been directed towards standardization, which underlies on a responsible and sustainable social behavior of the organization. Thus arises one of the first rules to provide a supportive framework for it, the AA1000, created by the Account Ability Institute and published in 1999, allowing voluntarily to achieve certification through three standards: the AccountAbility Principles 
Standard AA1000 (2008), Sustainability Assurance AA1000AS (2008), and the Commitment to Stakeholders Standard AA1000SES (2005), which points out, on including the stakeholders on issues and concerns regarding the sustainability of the organization that will have an impact on their economic, environmental, social and financial performance in the long term, and from this, the way in which the organization will formulate its strategy, and manage its performance. While in the AA1000AS (2008) the requirements are provided to ensure the sustainability of the organization. Thus, developed by Foretica in 1999, the SGE 21 standard emerges, aimed at promoting a system of ethical and socially responsible management of the organizations by means of nine management areas that establish the requirementsfor:seniormanagement, customers, suppliers, people within theorganization, socialsurroundings, environmental surroundings, investors, competition and government (SGE 21, 2008).

In full agreement with the guiding principles of sustainability, the social, economic, and environmental, the International Organization for Standardization (2010), and its ISO 26000:2010, it considers the most likely impacts on society, economy and environment to be addressed by organizations. For that, it takes into account seven core subjects: organizational governance; human rights, civil and political rights; labor practices; environment; fair operating practices; consumer issues, and active participation and community development.

Another specific contribution particularly considering improving working conditions is provided by the SA8000 standard from Social Accountability International (2014), being the first that incorporates the basic rights of workers: health and safety, freedom of association, maximum working hours, compensation, and guarantees against child labor, forced labor, and discrimination. SA8000 states that the organization must comply with local, and national laws, and industry standards prevailing where it is located, since the more favorable to workers will be applied in comparison to the proposal of the standard. It considers nine requirements for a socially responsible organization regarding: child labor, forced and compulsory labor, health and safety, freedom of association, and the right to collective bargaining, discrimination, disciplinary practices, number of working hours, remuneration and management systems (Social Accountability International, 2014).

For the business context of Mexico, the Mexican Center for Philanthropy 
is the nonprofit organization that distinguishes companies as socially responsible, underfourfactors: ethics and corporate governance, quality of life in the company, relationship and commitment to the community and its development, care and preservation of the environment (Cemefi, 2010). However, the flag is obtained through a questionnaire, without evidencing that companies do meet their act responsibly.

While these models have encouraged companies to take responsibility of their operations to a greater or lesser degree to achieve sustainable development; parallel from a growing market perspective, the paradigms of investment are changing, heading to those companies that besides presenting financial information, do it in terms of their sustainability (environmental and social). Which has led to the creation of stock indexes of sustainability and corporate social responsibility that track the performance of companies that demonstrate strong environmental, social, and governance practices (FTSE, 2014). Two global indexes stand out, the Dow Jones Sustainability Index, and the FTSE 4Good index series, both based on the methodology of Experts in Responsible Investments (EIRIS), and with environmental indicators such as: climate change, water consumption, biodiversity, pollution and resources. Social indicators regarding consumer responsibility, human rights, labor standards, health and safety. And governance indicators such as anti-corruption, fiscal transparency, risk management, and corporate governance. Thesameway, throughEcovalores, Mexico has implemented an approach to this EIRIS methodology, and has developed the IPC index, sustainable under three main areas: environmental responsibility, and indicators such as: water consumption; air emissions; residual water; waste; energy, and biodiversity. Social responsibility with the following indicators: principles and rights in labor relations; implementation of the code of ethics inside and outside the organization; quality of life, and personal development of its employees; and suppliers; collaboration between the organization, and; State and society. Corporate governance through: shareholder rights in the field, and; of property and equitable treatment; role of stakeholders; related parties, and conflicts of interest; disclosure; transparency and internal control; responsibilities, and structure of the board; independent directors; seniority and assistance, and; code of ethics (Mexican Stock Market, no year). Although a good start, today no Mexican company belongs to the Dow Jones Sustainability, nor the FTSE 4Good. 


\section{RESEARCH METHOD}

This is a documentary descriptive research on the review of social responsibility models. The most cited were selected, especially those generated by International Agencies: The United Nations (1999), The Commission of European Nations (2001), The Mexican Center for Philanthropy (2010), ISO 26000: 2010 (2010), the Global Report Initiative (2011), and Ethos (2011). The objective that the study outlined was based on identifying the factors of social responsibility and sustainability to be considered by the Mexican corporate sector.

The method used consisted of a documentary content analysis of the cited models with the support of software atlas.ti 7. Thereby identifying the common and more frequent factors (criteria) in CSR, and sustainability models, contrasted with those proposed by the Cemefi (Annex 1).

The analytic hierarchy process (AHP) was applied to these identified, and more common factors (a total of seven, now called criteria). The objective set in the AHP was to select the most suitable model for the Mexican business environment, for which, in the definition phase of actors, a single survey was conducted to a total of thirteen experts on social responsibility and sustainability in Mexico, with their numerical judgments, and the statistical modes of these, the criteria priorities were stablished, and according to the scale of Saaty on the relative importance between two alternatives, with values ranging from 1 equally preferred, to 9 highly recommended, and their respective reciprocal (Saaty, 2005, 1970).

\section{ANALYSIS-DISCUSSION}

Carrol (1979) is identified as the pioneer author of the study of corporate social responsibility, through four factors: 1. Economic. 2. Legal 3. Ethical 4. Discretionary or philanthropic. However, the international effort has focused on its development, as an example of this, we can find the United Nations Global Compact (1999), the Commission of European Nations on its Green Paper (2001), the models proposed by the Ethos organization (2011), and the Global Reporting Initiative (2011), in addition to various standards complementary to each other: the Social Accountability International Standard (2001), the Account Ability AA1000 (2008), the Ethical and Socially Responsible Management Standard SGE 21 (2008), and ISO 26000: 2010 (2010), however all voluntary, and none of them with 
the purpose of mandatory certification that would imply formal, responsible, and sustainable actions of the companies.

Particularly for this type of cases, you can take the Mexican Center for Philanthropy (2010), which in a similar way, distinguishes those companies that are socially responsible, but show no serious commitment to their practices in this regard.

The factors that each of these organizations suggest, although variable in number, match in terms of rights and concepts, and in most cases are complementary. Therefore, the matching factors of each of the models focused on corporate social responsibility are shown in Annex.

It is 12 the total factors that make up Corporate Social Responsibility and Sustainability in eight models. According to the frequency analysis (Figure 1), only those with the highest values were considered (greater than 4), same ones that in correspondence to their value, determined the hierarchical value, that is, those models with the largest number of common factors, became the ones with the highest hierarchical value. From these results the hierarchical model was constructed (Figure 1).

\section{Figure 1. Hierarchical Model}

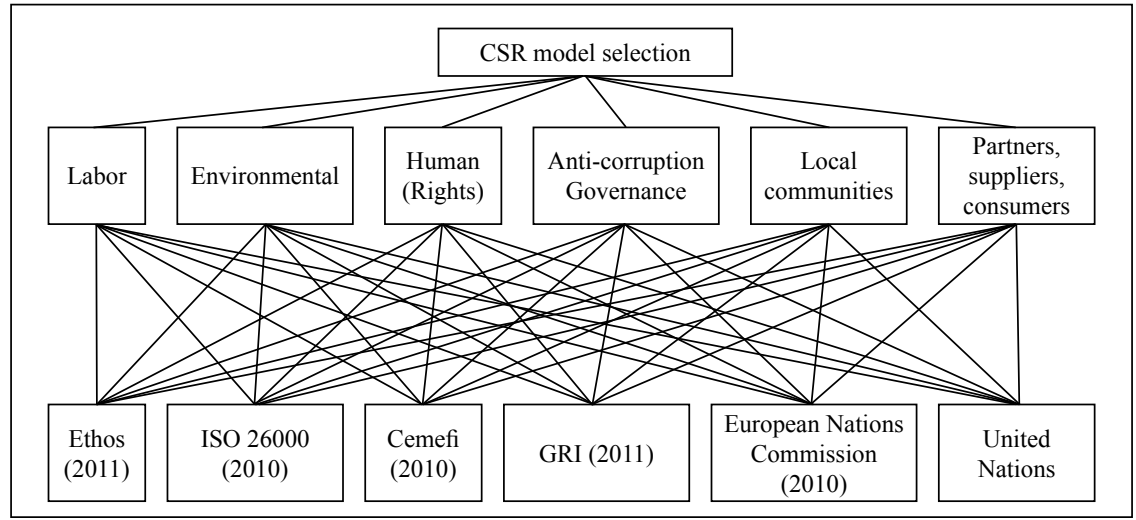

Source: Own elaboration.

At this point, the relative valuation between two alternatives was conducted through a survey of thirteen experts, on this, the statistical models were considered, and they settled as the value of the priorities of the criteria, according to the scale of importance of Saaty (Annex). The results 
of this matrix process of the AHP method are shownin Table 1. The final results of the process of hierarchical analysis are summarized in Table 2.

Table 1. Vector Matrix Multiplication

\begin{tabular}{|c|c|c|c|c|c|c|c|}
\hline \multicolumn{6}{|c|}{ Eigenvector criteria } & \multirow[b]{2}{*}{$x$} & \multirow[b]{2}{*}{$\begin{array}{l}\text { Eigenvector } \\
\text { matrix }\end{array}$} \\
\hline Labor & Environmental & $\begin{array}{l}\text { Human } \\
\text { (rights) }\end{array}$ & $\begin{array}{c}\text { Anti-corruption } \\
\text { Governance }\end{array}$ & $\begin{array}{c}\text { Local } \\
\text { communities }\end{array}$ & $\begin{array}{l}\text { Partners, } \\
\text { suppliers, } \\
\text { consumers }\end{array}$ & & \\
\hline 0.345 & 0.342 & 0.393 & 0.363 & 0.414 & 0.382 & $x$ & 0.09807 \\
\hline 0.287 & 0.306 & 0.265 & 0.248 & 0.235 & 0.212 & $x$ & 0.41353 \\
\hline 0.103 & 0.169 & 0.031 & 0.192 & 0.155 & 0.156 & $x$ & 0.17515 \\
\hline 0.182 & 0.089 & 0.144 & 0.107 & 0.111 & 0.123 & $x$ & 0.18520 \\
\hline 0.051 & 0.057 & 0.091 & 0.037 & 0.051 & 0.076 & $x$ & 0.09702 \\
\hline 0.031 & 0.038 & 0.077 & 0.053 & 0.033 & 0.050 & $x$ & 0.03104 \\
\hline
\end{tabular}

Source: Own elaboration.

Table 2. AHP Results

\begin{tabular}{|c|c|c|c|}
\hline 0.3631 & $36 \%$ & Alternative A & Ethos (2011) \\
\hline 0.2765 & $28 \%$ & Alternative B & ISO 26000 (2010) \\
\hline 0.1409 & $14 \%$ & Alternative C & Cemefi (2010) \\
\hline 0.1143 & $11 \%$ & Alternative D & GRI (2011) \\
\hline 0.0585 & $6 \%$ & Alternative E & $\begin{array}{c}\text { European Nations } \\
\text { Commission (2010) }\end{array}$ \\
\hline 0.0467 & $5 \%$ & Alternative F & United Nations (2010) \\
\hline
\end{tabular}

Source: Own elaboration.

In this sense, to the Mexican context, the model proposed in conjunction and complementarity to Cemefi, with Ethos, and ISO 26000; consists of 7 dimensions, and the following indicators:

1. Values, Transparency and Corporate Governance: Legality, cor- porate governance, ethical commitment, anti-corruption commitment, fair competition, self-regulation of behavior, transparent relations with society, responsible political participation, social leadership, processes and decision-making structure, fair competition, promoting socialrespon- 
sibility in the value chain, respect for property rights, fair marketing practices.

2. Quality of life in the company (labor practices): Legality, employability and labor relations, social dialogue and participation, working conditions and social protection, work-family balance, training and human development, health and safety, respect for the individual, decent work.

3. Bonding, active participation, and community development: Legality, active participation in the community, job creation and skill development, research, technological development and innovation, value and income generation, health, social investment, education and culture.

4. Care and preservation of the environment: Legality, pollution prevention, sustainable use of resources, mitigation and adaptation to climate change, protection and restoration of the natural environment, protection and restoration of the natural environment, environmental education and culture, accountability towards future generations.

5. Human Rights: Civil and political rights.

6. Suppliers: Selection, evaluation and association with suppliers.

7. Consumers and Customers: Health protection and consumer safety, sustainable consumption, customer services, support and resolution of complaints and disputes, protection and privacy of consumer data, access to essential services, education and awareness, social dimension of consumption.

\section{CONCLUSIONS}

One conclusion that can be outlined in this study is that corporate social responsibility is a multidimensional construct (Mexican Center for Philanthropy, 2010; ISO 26000: 2010, 2010, Commission of the European Nations, 2001; United Nations, 1999; Carroll 1979, 1991), although with certain similarities regarding the number of factorial components, in terms of sustainability, some of them are divergent. Strangely voluntary.

A second conclusion which reinforces the previous one, is that with the exception of the model of Carroll (1979) with more than 30 years of existence, and an apparent loss of effect; even though the models of the United Nations (1999), the Commission of European Nations (2001), the Mexican Center for Philanthropy (2010) and ISO 26000: 2010 (2010), are coincident with the dimensions of the universal ways which integrate social responsibility 
into, economic, social, and environmental; none of them present indicators to analyze how the consumer perceives it, how it generates a corporate image from it, and therefore how it affects a possible future purchasing behavior (Alvarado \& Schlesinger, 2008). It is for this reason, that there is consensus that those organizations who incorporate social responsibility into their strategies, will be those that survive and develop in sustainable terms.

In sum, all models claim international fundamental rights for a company to be socially responsible. In principle they are respect for human and labor rights, beyond compliance with the requirement of the Law in this respect, and an ethical behavior in their actions.

The most frequent coincident factors in the models are oriented to: Labor, environmental, human (rights), anti-corruption governance, local communities, business partners, suppliers, and consumers.

For the business case of Mexico, they are prioritized according to the AHP and expert opinion; the Ethos models (2011) with $36 \%$ of hierarchical weight that should be applied to the Mexican context, followed by ISO 26000 (2010) with $28 \%$, Cemefi (2010) with $14 \%$, and the GRI
(2011) with $11 \%$. The above indicates that the model of Cemefi must be rethought, and adjusted, considering greatly the factors proposed by Ethos and ISO 26000.

\section{REFERENCES}

AccountAbility (2008a). Norma de Aseguramiento de Sostenibilidad AA1000 AS (2008). Retrieved 3 de mach 2014, from www. accountability21.net

AccountAbility (2008b). Norma de Principios de AccountAbility AA1000APS. Retrieved 7 march 2014, from www.accountability21.net

Alvarado, A., \& Schlesinger, W.M. (2008). Dimensionalidad de la responsabilidad social empresarial percibida y sus efectos sobre la imagen y la reputación: una aproximación desde el modelo de Carroll. Estudios Gerenciales, 24(108), 37-59.

Carroll, A. (1991). The Pyramid of Corporate Social Responsibility: Towards the Moral Management of Organizational Stakeholders. Business Horizons, 34(4), 39-48. Carroll,A. (1979). A three-dimensional conceptual model of corporate performance. The Academy of Management Review, 4(4), 497-505

Cemefi. (2014). Centro Mexicano para la Filantropía, A.C. Retrie- 
ved 7 march 2013, from http:// www.cemefi.org/esr/

Cemefi, (2010). Retrieved 13 january 2013, from http://www. cemefi.org/esr/images/stories/ pdf/esr/concepto_esr.pdf

Commission of the European Communities. (2011). Communication from the Commission to the European Parliament, the Council, the European Economic and Social Committee and the Committee of the Regions A renewed EU strategy 2011-14 for Corporate Social Responsibility. Retrieved 23 january 2014, from, http://eur-lex.europa.eu/LexUriServ/LexUriServ.do?uri=COM:2011:0681: FIN:EN:PDF

Commission of the European Communities. (2001). Libro verde. Fomentar un marco europeo para la responsabilidad social de las empresas. Retrieved 23 january 2014 , from http://eur-lex. europa.eu/LexUriServ/LexUriServ.do?uri=COM:2001:0366: FIN:ES:PDF

Correa, M. E., Flynn, S., \& Amit, A. (2004). Responsabilidad social corporativa en América Latina: una visión empresarial. Santiago de Chile: Naciones Unidas. Retrieved 20 january 2014, from www.eclac.org/publicaciones/ xml/4/14904/lc12104.pdf

Ethos (2011). Indicarores Ethos de Responsabilidad Social Em- presarial. Retrieved 3 january 2013, from http://www1.ethos. org.br/EthosWeb/arquivo/0-Abbe2011_Indic_ETHOS_ESP. pdf

European Nations Commission. (1999). Towards environmental pressure indicators for the $E U$.

Global Report Initiative, (2011). G4 Sustainability Reporting Guidelines. Retrieved 16 december 2013, from https://www.globalreporting.org/resourcelibrary/GRIG4Part1-Reporting-Principles-andStandard-Disclosures.pdf

Friedman, M. (1970). The social responsibility of business is to increase its profits. The New York Times Magazine. 122-126.

FTSE, (2014). TSE Integrating ESG into investments and stewardship. Retrieved 7 january 2015, from http://www.ftse.com/products/downloads/FTSE-ESGMethodology-and-Usage-Summary-Short.pdf

García de los Salmones, M., Herrero A., \& Rodríguez I., (2005). Influence of corporate social responsibility on loyalty and valuation of services. Journal of Business Ethics, 61(4), 369-385. Hernández, R., Fernández, C. \& Baptista, M. (2010). Metodología de la investigación. México: Mc Graw-Hill.

ISO 26000:2010. (2010). Guía de responsabilidad social. Suiza: ISO. 
Kim, J.W., Kim, E.J., Kim, S.M., \& Hong H.G. (2011) Effects of fit with CSR activities and consumption value on corporate image and repurchase intention. International Journal of Business Strategy, 11(1), 35-53.

Labandeira, X., León, C. J., \& Vázquez. M.A. (2007). Economía Ambiental.Madrid:PearsonPrentice Hall.

Lámbarry, F., Rivas, L., \& Trujillo, M. (2013). Desarrollo de una escala de medición de la percepción en la calidad del servicio en los sistemas de autobuses de tránsito rápido a partir del Metrobús de la Ciudad de México. Innovar, 23(50), 79-92.

Landero, R., \& González, M. (2009). Estadística con SPSS y metodología de la investigación. México: Trillas.

Maignan, I. (2001). Consumers' perceptions of corporate social responsibilities: A cross-cultural comparison. Journal of Business Ethics, 30(1), 57-72.

Mercado, P., \& García, P. (2007). La Responsabilidad Social en empresas del Valle de Toluca (México). Un estudio exploratorio. Estudios Gerenciales, 23(102), 119-135.

Mexican Stock Market, (no year). Metodología EIRIS para la Evaluación Ambiental, Social y Ética de las empresas listadas en la
Bolsa Mexicana de Valores. Retrieved 7 december 2013, from http://www.bmv.com.mx/wb3/ $\mathrm{wb} / \mathrm{BMV} /$ responsabilidad_social

National Development Plan 20132018, (2013). Plan Nacional de Desarollo. Retrieved 19 april 2014, from http://www.inm.gob. mx/static/pdf/PND_2013-2018. pdf

National Institute of Statistics and Geography, 2009. Micro, pequeña, mediana y gran empresa. Estratificación de los establecimientos. Retrieved 19 april 2014, from http://www.inegi.org.mx/ est/contenidos/espanol/proyectos/censos/ce2009/pdf/Mono Micro_peque_mediana.pdf Mohr, L.A., Webb, D.J., \& Harris, K., (2001). Do consumers expect companies to be socially responsible? The impact of corporate social responsibility on buying behavior. Journal of Consumer Affairs, 35(1), 45-72

Pérez, A., \& Rodríguez I. (2011). Estudio de la imagen de responsabilidad social corporativa: formación e integración en el comportamiento del usuario de servicios financieros. Universidad de Cantabria- Departamento de Administración de Empresas. Retrieved 16 march 2013, from www.tdx.cat/handle/10803/ 36868 
Romo, A.M., \& Rodríguez, K.E. (2013). Percepción del consumidor en la actuación de las empresas socialmente responsables. Temas de comunicación, (26), 35-48.

Saldaña, A.J. (2010). Responsabilidad social empresarial: hacia una agenda de investigación en México. Revista y Organizaciones, 12(24), 75-89.

Sistema de Gestión y Socialmente Responsible SGE 21 (2008). Retrieved 13 december 2013, from http://sge21.foretica.org/wpcontent/uploads/2011/11/SGE21_2008_ES-DEF.pdf

Smith, N. C. (2003). Corporate social responsibility: Whether or how? California Management Review, 45(4), 52-76.

Social Accountability International (2014). SA8000: 2014. Retrieved 13 december 2014, from http://www.sa-intl.org/index. cfm? fuseaction=Page. ViewPage\&pageId $=937$

Strandberg, L. (2010). La medición y la comunicación de la RSE: indicadores y normas. Cuadernos de la Cátedra "la Caixa" de Responsabilidad Social de la Empresa y Gobierno Corporativo. $N^{\circ}$ 9. Diciembre de 2010 Business School Universidad de Navarra.

United Nations. (s.f.). Los Diez Principios del Pacto Mundial. Retrieved 18 february 2014, from http://www.unglobalcompact.org/Languages/spanish/ Los_Diez_Principios.html

World Business Council for Sustainable Development. (1998). Corporate Social Responsibility. Retrieved 20 november 2014, from http://www.wbcsd. org/work-program/businessrole/previous-work/corporatesocial-responsibility.aspx 


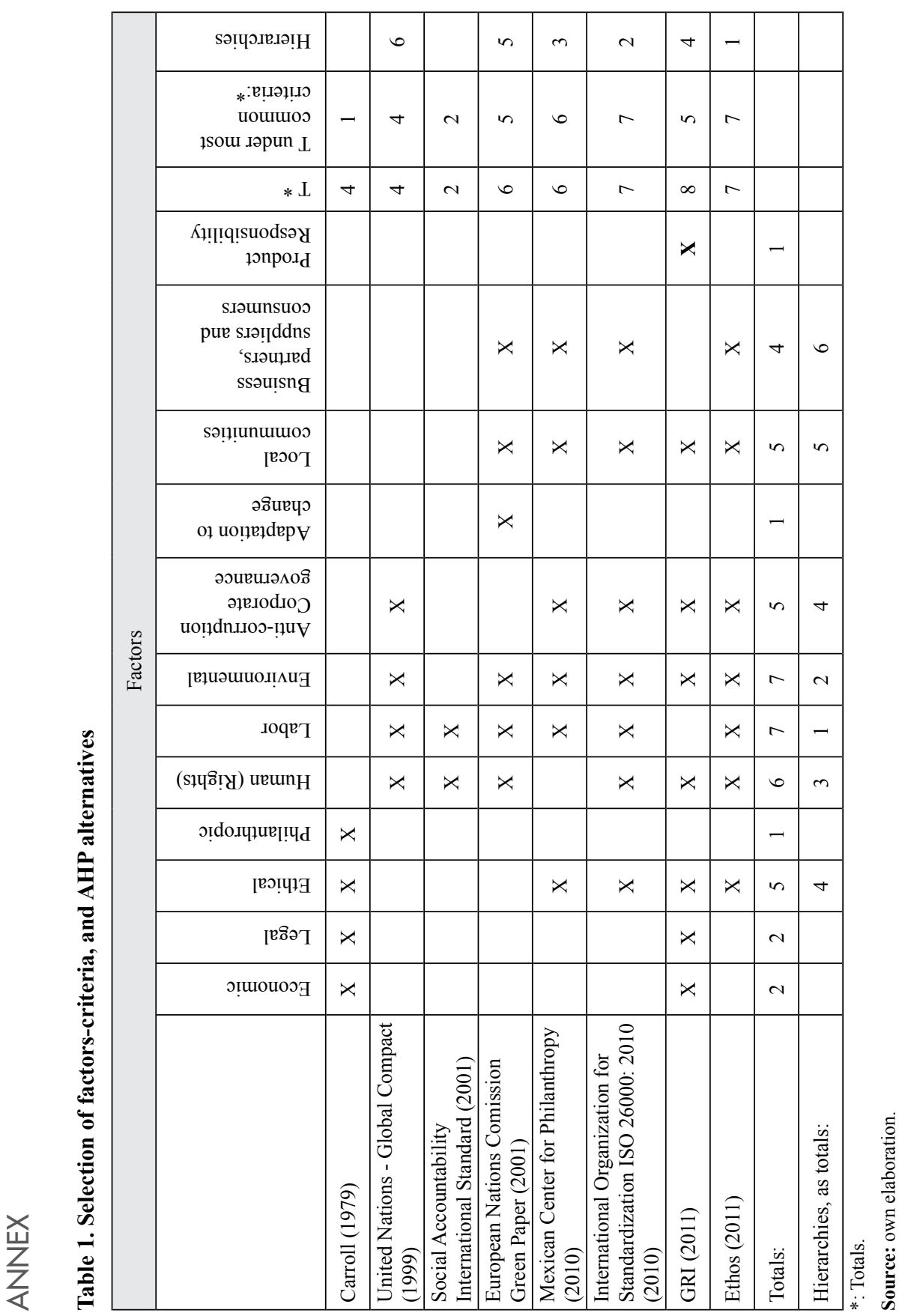

